\title{
The effect of market segmentation strategy on purchasing decisions of panties pizza in surabaya
}

\author{
Ananda Dwi Lestari ${ }^{\mathrm{a}^{*}}$,Agus Baktiono ${ }^{\mathrm{b}}$, Ani Wulandari ${ }^{\mathrm{c}}$ \\ ${ }^{a}$ Faculty of Economics and Business, Narotama University Surabaya, Jawa Timur, Indonesia, anandadwilestari239@gmail.com \\ ${ }^{b}$ Faculty of Economics and Business, Narotama University Surabaya, Jawa Timur, agus.baktiono@narotama.ac.id \\ ${ }^{c}$ Faculty of Economics and Business, Narotama University Surabaya, Jawa Timur, ani.wulandari@narotama.ac.id
}

\begin{abstract}
This study aims to analyze the effect of market segmentation strategies on purchasing decisions of Panties Pizza in Surabaya. The type of research is quantitative and SPSS 16 was employed to test the hypotheses with multiple linear regression analysis. The population in this study was the customers of Panties Pizza in Surabaya. The sampling technique used was non probability sampling with a purposive sampling approach with as many as 100 respondents who have purchased Panties Pizza. The results of this study indicated that the variables of geographical segmentation, demographic segmentation, and psychographic segmentation have a significant effect simultaneously on purchasing decisions in Panties Pizza Surabaya. The coefficient of determination is $62 \%$ and the rest was influenced by other variables not examined in this study. Geographical segmentation variables had a significant effect partially on the decision to purchase Panties Pizza in Surabaya with a significance value of $0.004<0.05$. Demographic segmentation variables had no significant effect partially on the decision to purchase Panties Pizza in Surabaya with a significance value of $0.722>0.05$. Psychographic segmentation variables had a significant effect partially on purchasing decisions of Panties Pizza in Surabaya with a significance value of $0,000<0.05$. The variables of geographical segmentation, demographic segmentation, and psychographic segmentation that possessed a significant influence psychographic segmentation with value of $\beta=0.644$.
\end{abstract}

Keywords: geographical, demographic, psychographic, purchasing decisions

\section{Introduction}

The business world today is getting tougher in competition. Economic globalization and technological advances have made business people free to penetrate international markets, consumers are increasingly free to choose the type and quality of products because consumers are currently faced with many alternative choices of products to consumer.

Marketing is the most important thing in a company because marketing is the driving force of a company to achieve success. Appropriate and effective marketing strategies such as promotional policies, pricing strategies, the right distribution process, and getting to know the market environment. This can determine the increase in sales and the position of the company (product) in the market.

In marketing products, the issue of consumer behaviour is a major factor that must be considered in the current era of highly competitive competition, such as who will buy, who influences consumers in making product purchases. In connection with the question of who will become consumers, basically the marketing study is very much related tothe problem of segmenting-targeting-and positioning (STP).

Consumer behaviour is also related to the problem of purchasing decisions, where in making a purchasing decision for a particular product, consumers will be influenced by many factors and undergone a process. The purchase decision is the stage in the decision making process of the buyer where the consumer actually buys the product. The purchase decision is the consumer's decision to buy a product after previously thinking about the appropriateness of buying the product by considering the information he knows about the reality of the product after he witnessed it.

\footnotetext{
* Corresponding author.

E-mail address: anandadwilestari239@gmail.com (Ananda Dwi Lestari)
} 
Like the pizza food business, known as food for the upper middle class because of the high price. This has become a business opportunity to open a pizza food business at a low price with the best quality, so that pizza can be enjoyed by all groups, ranging from upper middle to lower classes.

At this time the pizza business began to be developed at a more economical and affordable price, thus business people began to take advantage of these opportunities. One of them is panties pizza which is an economical and affordable pizza business allowing it to be enjoyed by all groups. Panties pizza is a "calzone" dish, a kind of semi-circular folding pizza with a fairly large size originating from Italy. Unlike pizza in general, which is circular in shape with the topping on the surface.

Panties Pizza was established in May 2013 by Johan Permana in Solo, which was the first pizza business in Solo that serves a type of folding pizza. Panties Pizza began to develop to various major cities in Indonesia, so that now it has many branches in a number of regions in Indonesia. One of them is in Surabaya, there are three branches of Panties Pizza. First, grandly opened in June 2015, at Jl. Klampis Jaya 10C, the second branch was launched in December 2016 at JL. Mayjend Yono Soewoyo No. 64-64A (Jl. Raya Babatan Unesa), and the third opened in May 2017 at Tunjungan Plaza 2 LG 43-44. However, the first branch moved its location to Jl. Mleto 42C in June 2019. Among all the three branches of Panties Pizza in Surabaya, it always provides good service and attractive promos for their customers.

Panties Pizza is quite experienced in serving various variants of folding pizza with the shape not too large in size where 1 portion consists of 4 slices with distinctive flavours and its melted mozzarella cheese. This typical Italian food has a crispy texture on the outside but soft on the inside. The variety of tastes also varies and in the Panties Pizza menu there are unique names, such as the 1001 Night Pizza menu in the form of Calzone with meat and vegetable and kebab as the stuffing ingredients, Broadway Pizza with smoked beef filling, Tuna Maya with tuna fish fillings. Panties Pizza provides a unique menu name aimed to attract the attention of visitors. This is one of the factors that makes Panties Pizza able to grow to various big cities in Indonesia. Market segmentation in panties pizza varies from teenagers to families. Even though the price is cheap it does not mean that these it is a cheap products, Panties Pizza use a high quality ingredients. However there are still many who think that Panties Pizza is known to be expensive.

\section{Literature review}

\subsection{Market Segmentation Strategy}

According to Boyd, Harper W., (2000: 194) Market segmentation is a process where the market is divided into customers consisting of people with the same needs and characteristics that direct them to respond to product / service offers and marketing programs certain strategies in the same way.

\subsection{Geographical Segmentation}

According Kotler et al., (2016:268) Geographical segmentation divides markets into geographical units such as countries, states, regions, districts, cities, or the environment. The company can operate in one or several areas, or operate in all but pay attention to local variations. That way it can adjust the marketing program to the needs and desires of local customer groups in the trade area, the environment, even individual stores. In a growing trend called grassroots marketing, marketers concentrate on making activities that are personally relevant to individual customers. The indicator that used on this research are sourced from Sofjan Assauri (2015: 155) quoted in the journal Ahmadi \& Herlina (2017):
1. Region
2. Climate
3. City or village

\subsection{Demographic Segmentation}


According to Kotler et al., (2016:271) demographic variables are age, family size, family life cycle, gender, income, occupation, education, religion, race, generation, nationality, and social class are very popular among Marketers are that they are often associated with consumer needs and wants. Demographic characteristics aim to estimate the size of the market and the media how to use it to achieve them efficiently. The indicator used in this research sourced from Kotler et al., (2016) which are:

1. Age and Life-Cycle Stage

2. Religion

3. Profession or occupation

4. Gender

5. Revenue

\subsection{Psychographic Segmentation}

According to Kotler et al., (2016:280) Psychography is the science of using psychology and demographics to better understand consumers. In psychographic segmentation, buyers are divided into groups based on psychological / personality traits, lifestyle, or values. People in the same demographic group can show very different psychographic profiles. The indicator that used in this research sourced from Indriyo (2009) quoted in the journal Fullchis et al., (2017):

1. Social Class

2. Lifestyle

3. Personality

\subsection{Purchasing Decisions}

According to Kotler and Armstrong (2012:181) quoted in the journal of Ahmadi \& Herlina (2017) states that consumer purchasing decisions are buying the most preferred brand of various alternatives, however the two factors can be between purchase intentions and purchasing decisions.

The indicator that used in this research are sourced from Kotler (2009: 145) in the journal Fullchis et al., (2017):

1. Introduction

2. Search

3. Evaluation

4. Purchasing Decisions

5. Behavior after Purchase

\subsection{Hypothesis}

H1: Geographical segmentation, demographic segmentation, and psychographic segmentation significantly and simultaneously influence purchasing decisions.

H2: Geographical segmentation significantly and partially influence purchasing decisions.

H3: Demographic segmentation significantly and partially influence purchasing decisions.

H4: Psychographic segmentation partially and significantly influence purchasing decisions.

H5: Demographic segmentation has the most dominant influence on purchasing decisions. 


\section{Conceptual framework}

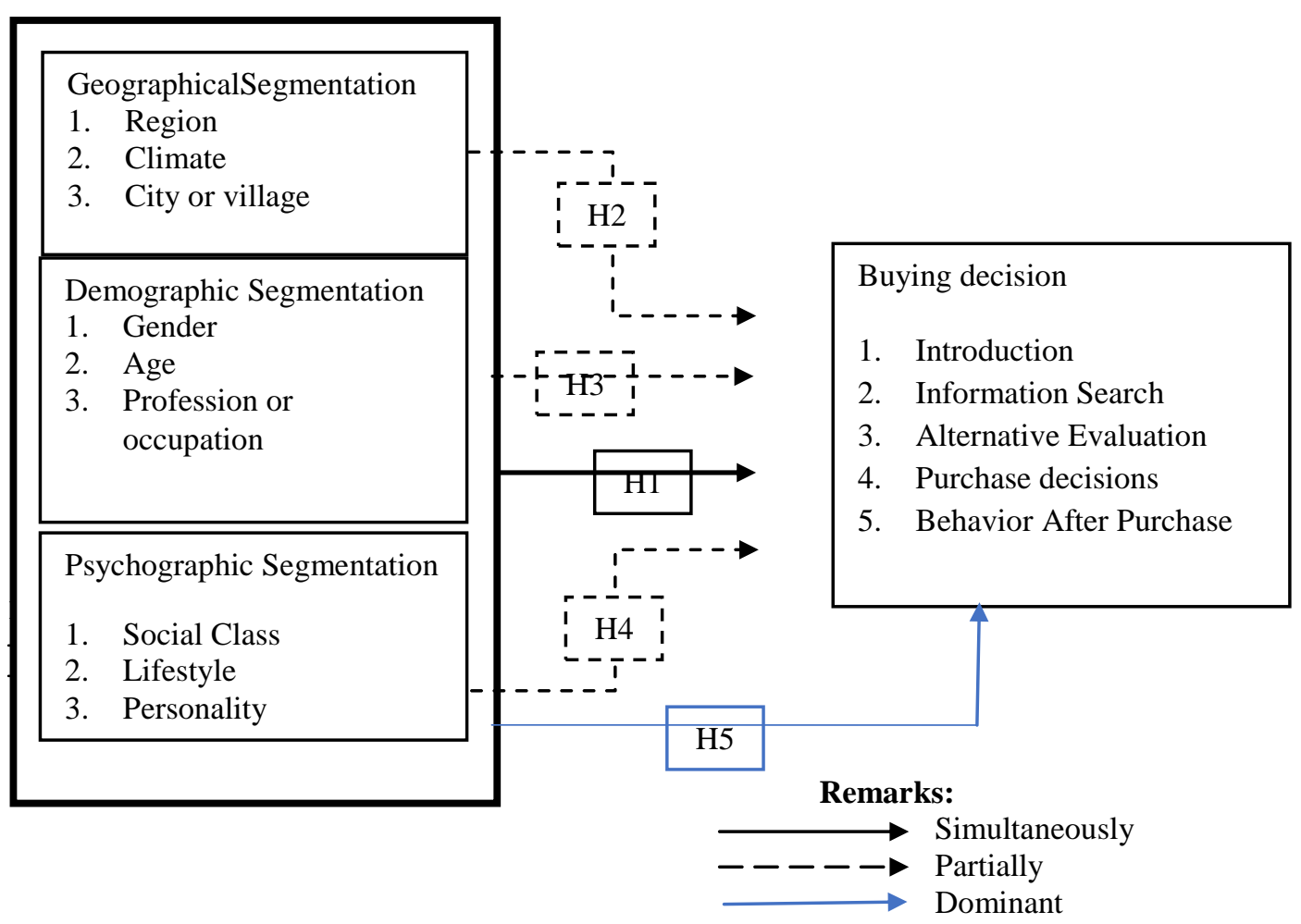

\section{Methodology}

This study uses a quantitative approach. The object of research was conducted in three branches of Panties Pizza Surabaya. The sampling is customers who have purchased Panties Pizza Surabaya. The data collection techniques using a questionnaire. Scale measurement using a Likert scale. Data were processed using SPSS version 16. Data analysis techniques employed multiple linear regression using validity, heteroscedasticity, Multicollinearity, correlation analysis and determinant analysis consisting of the $\mathrm{F}$ test and $\mathrm{t}$ test.

\section{Result and Discussion}

Table 1 Validity Test

\begin{tabular}{cccc}
\hline Variabel & Item & $\begin{array}{c}\text { Corrected Item-Total } \\
\text { Correlation }\end{array}$ & Rtabel \\
\hline X1 & X1.1 & 0.338 & 0,196 \\
& X1.2 & 0.585 & 0,196 \\
X2 & X1.3 & 0.607 & 0,196 \\
& X2.1 & 0.590 & 0,196 \\
& X2.2 & 0.490 & 0,196 \\
& X2.3 & 0.483 & 0,196 \\
& X2.4 & 0.413 & 0,196 \\
& X2.5 & 0.575 & 0,196 \\
\hline
\end{tabular}




\begin{tabular}{cccc}
\hline X3 & X3.1 & 0.629 & 0,196 \\
& X3.2 & 0.614 & 0,196 \\
& X3.3 & 0.687 & 0,196 \\
Y & Y1 & 0.668 & 0,196 \\
& Y2 & 0.640 & 0,196 \\
& Y3 & 0.671 & 0,196 \\
\hline
\end{tabular}

Testing the validity of the indicators of all independent and dependent variables shows valid, because the value of $\mathrm{R}$ statistic > R table is 0.196 . Thus it can be stated that all statements on the instrument variables in this study are valid.

Table 2 Reliability Test

\begin{tabular}{cc} 
Cronbach's Alpha & N of Items \\
\hline .889 & 14
\end{tabular}

The variable can be stated reliable because the data of this study have Cronbach's Alpha 0.889 and greater than 0.60.

Table 3 Multiple Linear Regression

\begin{tabular}{cc}
\hline \multirow{2}{*}{ Model } & Unstandardized Coefficients \\
& B \\
\hline (Constant $)$ & 0,278 \\
X1 & 0,282 \\
X2 & 0,024 \\
X3 & 0,644 \\
\hline
\end{tabular}

The regression equation of this research is:

$$
\mathrm{Y}=0.278+0.282 \mathrm{X}_{1}+0.024 \mathrm{X}_{2}+0.644 \mathrm{X}_{3}+\mathrm{e}
$$

From the equation above, it can be interpreted as follows:

a. Constants $=0.278$ indicate that all independent variables consist of geographical segmentation (X1), demographic segmentation (X2), psychographic segmentation (X3) is equal to 0 (zero), then the purchase decision (Y) is equal to 0.278 .

b. The value of the geographical segmentation coefficient $\left(\beta_{1}\right)$ of 0.282 shows that if the geographical segmentation variable (X1) is increased, it will result in an increase in purchasing decisions by 0.282 assuming the other independent variables are constant.

c. The demographic segmentation coefficient $\left(\beta_{2}\right)$ value of 0.024 shows that if the demographic segmentation variable (X2) is increased, it will result in an increase in purchasing decisions by 0.024 assuming the other independent variables are constant.

d. The value of the psychographic segmentation coefficient $\left(\beta_{3}\right)$ of 0.644 indicates that if the psychographic segmentation variable (X3) is increased, it will result in an increase in purchasing decisions of 0.644 assuming the other independent variables are constant.

Table 5 F Test (Simultaneously)

\begin{tabular}{cccc}
\hline F Statistic & F Table & Sig. & Remarks \\
\hline 54.913 & 2,47 & $<0.001$ & Significant \\
\hline
\end{tabular}

The value of $\mathrm{F}$ statistic is $54.913>\mathrm{F}$ table 2.47 with a significant level of $0.00<0.05$ in accordance with the provisions specified, thus it can be concluded that the independent variable of geographical segmentation (X1), demographic segmentation (X2), and psychographic segmentation (X3) simultaneously have a significant effect on the dependent variable which is purchasing decisions (Y).

Table 6 T Test (Partially)

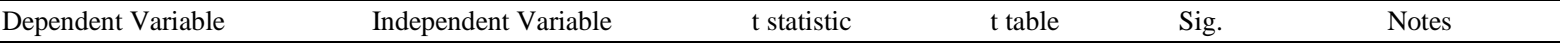




\begin{tabular}{lllllc} 
& X1 & 2,964 & 1.661 & $<0.001$ & Significant \\
Purchasing Decision (Y) & X2 & 0,357 & 1.661 & $<0.001$ & Not Significant \\
& X3 & 7,402 & 1.661 & $<0.001$ & Significant \\
\hline
\end{tabular}

a. Geographical Segmentation (X1) partially influenced Purchasing Decisions (Y). Based on the table above shows the effect of variable geographical segmentation (X1) on purchasing decisions (Y), the results of the analysis of geographical segmentation obtained $t$ statistic of 2,964 > t table of 1,661 or significant results of $0.004<0.05$ in accordance with established conditions, it can be concluded that geographical segmentation (X1) partially has a significant effect on purchasing decisions $(\mathrm{Y})$.

b. Demographic Segment (X2) partially affected Purchasing Decisions (Y). Based on the table above shows the influence of demographic variables (X2) on purchasing decisions $(\mathrm{Y})$, the results of demographic segmentation analysis obtained $t$ statistic of $0.357<t$ table of 1.661 or significant results of $0.722>0.05$, it can be concluded that demographic (X2) partially has no significant effect to the purchase decision (Y).

c. Psychographic Segmentation (X3) partially influence Purchasing Decisions (Y). Based on the table above shows the effect of psychographic segmentation variables (X3) on purchasing decisions (Y), the results of geographic segmentation analysis obtained $t$ statistic of $7402>t$ table of 1,661 or significant results of $0,000<0.05$ in accordance with the provisions set, it can be concluded that Psychographic segmentation (X3) partially has a significant effect on purchasing decisions (Y).

\subsection{Hypothesis testing}

\subsection{Hypothesis 1}

Geographical segmentation, demographic segmentation, and psychographic segmentation have a significant simultaneous effect on purchasing decisions at Panties Pizza Surabaya. The calculated $\mathrm{F}$ value $=54.913>\mathrm{F}$ table $=$ 2.47 with a significant level of $0.00>0.05$, it can be concluded that there is a significant influence between the independent variables namely geographical segmentation, demographic segmentation, and psychographic segmentation towards dependent variable which is purchasing decision in Panties Pizza. This is in accordance with research Fullchis et al., (2017) which states that geographical, demographic, psychographic and simultaneous variables have a significant influence on purchasing decisions. Therefore, the first hypothesis is accepted.

\subsection{Hypothesis 2}

Geographical segmentation has a significant effect partially on the decision to purchase Panties Pizza in Surabaya. As shown the obtained value of $\mathrm{t}$ arithmetic $=2.964>\mathrm{t}$ table $=1.661$ and a significant value of $0.004<0.05$, it can be concluded that geographical segmentation partially has a significant effect on purchasing decisions on Panties Pizza in Surabaya. Thus, the second hypothesis is accepted. This is consistent with research Anjelisa et al. (2018) which states that geographical variables significantly influence purchasing decisions.

\subsection{Hypothesis 3}

Demographic segmentation partially has no significant effect on the decision to purchase in Panties Pizza Surabaya. As observed, $\mathrm{t}$ count $=0.357<\mathrm{t}$ table $=1.661$ and a significant value of $0.722>0.05$, it can be concluded that the demographic segmentation partially does not significantly influence the purchase decision on Panties Pizza Surabaya. Since the decision to purchase Panties Pizza in Surabaya does not affected by the factors of gender, age, and profession or occupation. Then the third hypothesis is rejected. This is not in accordance with the research of Ahmadi \& Herlina (2017) which states that demographic variables significantly influence purchasing decisions.

\subsection{Hypothesis 4}

Psychographic segmentation partially has a significant effect on the decision to purchase Panties Pizza in Surabaya. The calculation obtained $\mathrm{t}$ count $=7.402>\mathrm{t}$ table $=1.661$ and a significant value of $0.000<0.05$, it can be concluded that 
psychographic segmentation has a partially significant effect on purchasing decisions on Panties Pizza Surabaya. That makes the fourth hypothesis accepted. This is consistent with research by Safitra (2017) which states that demographic variables have a significant effect on purchasing decisions.

\subsection{Hypothesis 5}

Psychographic segmentation which has the most dominant influence on purchasing decisions at Panties Pizza in Surabaya. Because the beta value of psychographic segmentation is 0.644 , the value that is the furthest from zero, so that it become the most dominant influence towards the purchase decision on Panties Pizza Surabaya. The regression coefficient for psychographic segmentation is the biggest among the other variables. This is This is not consistent with research by Prasetyo et al., (2017) which proves that demographic segmentation is the most dominant compared to psychographic segmentation. Then the fifth hypothesis is rejected.

\section{Conclusion}

\subsection{Conclusion}

1. Variable of geographical segmentation, demographic segmentation, and psychographic segmentation have a significant simultaneous effect on purchasing decisions on Panties Pizza in Surabaya. Value of $\mathrm{F}$ statistic $=$ $54.913>$ Ftable $=2.47$ with a significant level of $0.00<0.05$.

2. Geographical segmentation variable partially has a significant effect on the decision to purchase Panties Pizza in Surabaya. Significance value of $0.004<0.05$ means $(0.004$ is smaller than 0.05$)$.

3. Demographic segmentation variable partially has no significant effect on the decision to buy Panties Pizza in Surabaya. The significance value of $0.722>0.05$ means $(0.722$ is greater than 0.05$)$. This is based on the reason that the decision to buy Panties Pizza Surabaya does not affected by gender, age, and profession or occupation.

4. Psychographic segmentation variable partially has a significant effect on the decision to purchase Panties Pizza Surabaya. Significance value of $0,000<0.05$ means $(0,000$ is smaller than 0.05$)$.

5. Among the variable of Geographical segmentation, demographic segmentation, and psychographic segmentation, the one having the highest significant dominant effect towards buying decision is psychographic segmentation variables. Value of $\beta=0.644$.

\subsection{Recommendation}

The recommendation that can be given are:

1. Geographical segmentation variable is appropriate, however it needs to be considered again regarding regional factors, especially for the new location of the Klampis branch which is more remote, so that many consumers still know only the old Klampis branch. The suggestion is to give a complete information about the address of the new area of the Klampis branch.

2. Demographic Segmentation consists of factors of gender, age and profession / occupation. Pizza Panties is more in demand by women than men, ranging from the age group of 20-30 years with the profession of students / students and private employees. Therefore Panties Pizza must retain consumers with the profession of students and private employees aged 20-30 years, thus consumers stay loyal and also further enhance its marketing strategies by increasing more promotions that makes more consumers know about Panties Pizza.

3. Psychographic Segmentation is found in lifestyle, social class, and personality. Today's consumers look more at lifestyle factors. Panties Pizza is known as a folding pizza that prioritizes mozzarella cheese with various flavors, thus Panties Pizza can adjust the lifestyle of today's consumers. Based on that reason, it will be better for Pizza Panties to create more new flavor variants so that consumers will not get bored.

4. The next researcher may employ other objects or add other variables that can influence purchasing decisions.

\section{References}

Ahmadi, N. K., \& Herlina. (2017). Analisis segmentasi terhadap keputusan pembelian produk eiger di bandar 
lampung. Jurnal Manajemen Magister, 03(01), 75-95. https://jurnal.darmajaya.ac.id

Anjelisa, Mananeke, L., \& Rogi, M. S. (2018). Analisis Pengaruh Strategi Segmentasi, Targeting Dan Positioning (Stp) Terhadap Keputusan Pembelian Produk Bp-Smart Protection Di Ajb Bumiputera 1912 Cabang Sam Ratulangi Manado. Jurnal EMBA: Jurnal Riset Ekonomi, Manajemen, Bisnis Dan Akuntansi, 6(4), 4073-4082.

Fullchis Nurtjahjani, Asminah Rachmi, M. (2017). Pengaruh Segmentasi Pasar Terhadap Keputusan Pembelian Produk Telkom Speedy Di Pt Telekomunikas Indonesia Cabang Malang. Jurnal Administrasi Dan Bisnis, 11, Nomor, 107-114.

Kotler, P., Keller, K., Brady, M., Goodman, M., \& Hansen, T. (2016). Marketing Management Fifteenth Edition. https://doi.org/10.1080/08911760903022556

Prasetyo, L. D., Moniharapon, S., \& Loindong, S. (2017). Pengaruh Faktor-Faktor Segmentasi Demografis Dan Segmentasi Psikografis Terhadap Keputusan Pembelian Pada Matahari Department Store Mtc Manado. Jurnal Riset Ekonomi, Manajemen, Bisnis Dan Akuntansi, 5(2), 1337-1347.

Safitra, R. (2017). Analisis Pengaruh Strategi Segmenting, Targeting dan Positioning Terhadap Keputusan Pelanggan Membeli Nu Green Tea. Jurnal Ekonomika Dan Manajemen, 6(1), 28-44. 